\title{
SISTEM PENDUKUNG KEPUTUSAN PENERIMAAN BEASISWA MENGGUNAKAN ALGORITMA C4.5 (STUDI KASUS : BAITUL MAAL)
}

\author{
Agustiena Merdekawati \\ Manajemen Informatika, AMIK Bina Sarana Informatika \\ email: agustiena.atd@bsi.ac.id
}

\begin{abstract}
Abstrak
Beasiswa merupakan sebuah cara untuk mengatasi masalah biaya atau ekonomi bagi mereka yang kurang mampu. Beasiswa adalah pemberian berupa bantuan keuangan yang diberikan kepada perorangan yang bertujuan untuk digunakan demi keberlangsungan pendidikan yang ditempuh. Pemberi beasiswa, yaitu lembaga pemerintahan, perusahaan, atau yayasan. Pemberian beasiswa ini sangat penting, guna memberikan ketenangan mereka dalam mengikuti belajar-mengajar. Namun terkadang pemberian beasiswa tidak pada orang yang seharusnya menerima atau tidak tepat pada sasarannya. Dari permasalahan tersebut dilakukan penelitian mengenai seleksi penerimaan beasiswa dengan menggunakan algoritma C4.5. Setelah dilakukan pengujian, maka hasil yang didapat dari algoritma C4.5 memiliki akurasi sebesar $69.73 \%$. Dengan adanya penelitian diharapkan dapat membantu baitul maal atau pemberi beasiswa dalam menentukan kriteria yang lebih diutamakan untuk pemberian beasiswa, sehingga pemberian beasiswa dapat tepat sasaran.
\end{abstract}

Kata kunci: Pendukung keputusan, Beasiswa, Algoritma C4.5

\begin{abstract}
Scholarships are a way to address cost or economic issues for the underprivileged. The scholarship is a grant of financial assistance given to individuals who aim to be used for the sustainability of education pursued. Scholarship grantee, ie government institution, company, or foundation. The provision of scholarships is very important, in order to provide their calm in following the teaching and learning. But sometimes scholarships are not on people who should receive or not right on the target. From the problem is done research about the selection of scholarship acceptance by using algorithm C4.5. After testing, the results obtained from the algorithm $\mathrm{C4.5}$ has an accuracy of $69.73 \%$. With the research is expected to help baitul maal or scholarship in determining the criteria that are preferred for the provision of scholarships, so that the scholarship can be right on target.
\end{abstract}

Keywords: Decision support, Scholarships, Algorithms C4.5

\section{PENDAHULUAN}

Seperti yang dituangkan dalam Undang-Undang Dasar 1945 pasal 31 (1) bahwa tiap warga negara berhak mendapatkan pengajaran. Akan tetapi untuk mendapatkan pendidikan itu semakin tidak terjangkau atau sangatlah mahal, terutama bagi yang bertingkat ekonomi menengah kebawah, baik itu tingkat SD, SMP, SMA, bahkan perguruan tinggi.

Beasiswa merupakan salah satu solusi untuk mengatasi masalah biaya bagi mereka yang kurang mampu.
Menurut Murniasih dalam Rainer (2017) beasiswa diartikan "sebagai bentuk penghargaan yang diberikan kepada individu agar dapat melanjutkan pendidikan kejenjang yang lebih tinggi".

Sehingga dengan adanya beasiswa dapat menciptakan pengaruh yang positif bagi mereka, yaitu:

1. Mereka tidak perlu lagi khawatir dengan tagihan biaya pendidikan,

2. Anak tersebut berusaha untuk mendapatkan nilai dan prestasi yang tinggi. 
Dalam Penelitian Hijriana dan Rasyidan (2017), dengan kesimpulan Atribut yang berpengaruh terhadap proses seleksi calon penerima beasiswa adalah Indeks Prestasi Semester, Penghasilan yang dibuat menjadi 3 atau 4 kategori kelas (Klasifikasi Penghasilan) dan Tanggungan, baik dengan 2 kategori kelas maupun dengan 3 kategori kelas (Klasifikasi Tanggungan). Sehingga data atribut Penghasilan dan Tanggungan akan lebih berpengaruh dalam penentuan nilai akurasi jika diubah ke dalam bentuk klasifikasi terlebih dahulu dibandingkan jika hanya dengan data asli berupa angka. Hasil evaluasi dengan tool Confussion Matrix yang ditunjukkan melalui tabel Performance Vector C4.5 dan validasi dengan teknik Split Validation menunjukkan tingkat akurasi tertinggi didapat pada eksperimen ke-10 yakni sebesar $85.44 \%$, dengan nilai class precision berturutturut sebesar $87.61 \%$ dan $77.66 \%$ dan nilai class recall sebesar $93.54 \%$ dan $62.93 \%$.

Berdasarkan kesimpulan dalam penelitian Praja dan Astuti (2016) adalah berdarkan hasil pengujian metode pohon keputusan terhadap data siswa dapat disimpulkan bahwa, Penerapan metode pohon keputusan terhadap data siswa SMA N 1 Mlonggo memiliki tingkat akurasi yang cukup baik dalam menyelesaikan klasifikasi rekomendasi beasiswa. Metode pohon keputusan merupakan metode yang cukup sesuai untuk penyelesaian studi kasus dalam pemilihan siswa yang mendapatkan rekomendasi beasiswa. Tingkat akurasi yang dihasilan oleh metode tersebut adalah $79 \%$.

Dalam penelitian Gutterres, beasiswa merupakan sarana yang diberikan dan diajukan oleh instituti pendidikan guna membantu para mahasiswa yang kurang mampu namun memiliki segudang prestasi dalam bidang akademik. Untuk menentukan Mahasiswa layak atau tidak menerima beasiswa maka diperlukan sebuah sistem yang dapat memberikan kemudahan dalam pengajuan penerima beasiswa. Tujuan dari penelitian ini untuk menguji kelayakan algoritma C4.5 sebagai pendukung keputusan dalam pengajuan penerima beasiswa pada STIKOM Artha Buana. Metode yang digunakan adalah metode klasifikasi menggunakan algoritma C45 dengan kriteria antara lain Tidak memiliki kendaraan pribadi, jarak tempat tinggal jauh $\pm 2 \mathrm{Km}$ dari kampus, IPK minimal 2,75 , belum pernah mendapatkan beasiswa dan penghasilan orang tua $<1$ juta. Hasil dari penelitian adalah menentukan mahasiswa sebagai calon yang seharusnya diajukan oleh kampus STIKIM ARTHA BUANA Kupang untuk menerima beasiswa pendidikan berdasarkan hasil perhitungan algoritma C45. Dari hasil perbandingan metode, maka dapat diambil kesimpulan bahwa algoritma C45 layak dijadikan sebagai pendukung keputusan dalam pengajuan penerima beasiswa pada Stikom Artah Buana kupang karena hasil persentasi dari algoritma C45 lebih tinggi daripada metode klasifikasi yang lainnya dan memiliki kendaraan pribadi juga layak dijadikan salah satu kriteria dalam pengajuan penerima dana bantuan beasiswa dari pemerintad daerah ataupun dari dikti/kopertis wilayah 8.

Akan tetapi, pengambilan keputusan masih terdapat beberapa permasalahan yang harus dicarikan solusi terbaik, yang berisi elemen-elemen atau hubunganhubungan antar elemen yang tidak dapat dipahami dimana masalah tak terstuktur terjadi.

Sedangkan masalah semi terstruktur adalah masalah yang berisi sebagian elemen-elemen atau hubungan yang dimengerti oleh pemecah masalah.

Menurut Hasan SPK dirancang untuk mendukung seluruh tahap pengambilan keputusan mulai dari mengidentifikasi masalah, memilih data yang relevan, menentukan pendekatan yang digunakan dalam proses pengambilan keputusan sampai mengevaluasi pemilihan alternative. Sistem pendukung keputusan (SPK) adalah sebuah sistem yang dimaksudkan untuk mendukung para pengambilan keputusan semi terstruktur. Sistem Pendukung Keputusan (SPK) yang dimaksud untuk menjadi alat bantu bagi para pengambil keputusan untuk memperluas kapasitas, namun tidak untuk 
menggantikan penilaian. (Ahda dan Bahri, 2017)

Pada dasarnya pengambilan keputusan adalah suatu pendekatan sistematis pada hakekat suatu masalah, pengumpulan fakta-fakta, penentuan yang matang dari alternatif yang dihadapi dan pengambilan tindakan yang menurut perhitungan merupakan tindakan yang paling tepat. Sekalipun didukung oleh potensi ekosistem dan aksebilitas yang serba prospektif, pengambilan keputusan kerap dihadapkan pada masalah utama dalam penentuan keputusan strategis yang sulit direalisasikan akibat persepsi yang heterogen sejalan dengan kepentingan masing-masing individu/kelompok yang terlibat dalam pengambilan keputusan. (Suryadi, 2007)

Setiap tahunnya yayasan baitul maal menyediakan beasiswa bagi siswa atau siswi di Indonesia yang kurang mampu dan berprestasi. Akan tetapi tidak semua pendaftar mendapatkan beasiswa. Sistem seleksi beasiswa yang tidak akurat menyebabkan beasiswa salah sasaran.

Penelitian mengenai analisis kelayakan pemberian beasiswa dengan metode klasifikasi data mining telah banyak dilakukan, namun sangat jarang sekali yang menganalisis kelayakan pemberian beasiswa untuk SD, SMP, SMA, dan dengan mengunakan pengujian tingkat keakuratan dengan menggunakan Rapidminer.

Manfaat penelitian ini adalah:

1. Manfaat Praktisi, hasil penelitian ini diharapkan agar dapat digunakan oleh baitul maal dalam penentuan seleksi pemberian beasiswa bagi SD, SMP, dan SMA.

2. Manfaat teoritis, hasil penelitian ini diharapkan dapat memberikan sumbangan bagi penelitian yang berkaitan dengan klasifikasi data mining, khususnya dalam penentuan seleksi pemberian beasiswa bagi SD, SMP, dan SMA.

3. Manfaat kebijakan, dari penelitian ini diharapkan dapat memberikan hasil yang lebih akurat sehingga memudahkan bagian staff baitul maal untuk menyeleksi proses penerimaan beasiswa.
Menurut hermawati (2013:3) Data mining proses yang mempekerjakan satu atau lebih teknik pembelajaran komputer (machine learning) untuk menganalisis dan mengekstrasi pengetahuan (knowledge) secara otomatis. Definisi lain diantaranya adalah pembelajaran berbasis (induction-based learning) adalah proses pembentukan definisi-definisi konsep umum yang dilakukan dengan caramengobservasi contoh-contoh spesifik dari konsep-konsep yang akan dipelajari. Knowledge Discovery in Databases (KDD) adalah penerapan metode saintik pada data mining. Dalam konteks ini data mining merupakan satu langkah dari proses KDD.

Menurut Hermawati (2013:3) Data mining merupakan proses iterative dan interaktif untuk menemukan pola atau model baru yang sahih (sempurna), bermanfaat dan dapat dimengerti dalam suatu database yang sangat besar (massive databases).

a. Sahih

Dapat digeneralisasi untuk masa yang akan datang.

b. Baru Apa yang sedang tidak diketahui.

c. Bermanfaat

Dapat digunakan untuk melakukan suatu tindakan.

d. Iteratif

memerlukan sejumlah proses yang diulang

e. Interaktif

f. memerlukan interaksi manusia dalam prosesnya.

Menurut Hermawati (2013:14) teknik data mining dibagi menjadi beberapa teknik. Beberapa teknik dan sifat data mining adalah sebagai berikut:

a. Klasifikasi (Classification)

Menentukan sebuah record data baru kesalah satu dari beberapa katagori (atau klas) yang telah didefinisikan sebelumnya.

b. Regresi (Regression)

Memprediksi nilai dari suatu variabel kontinyu yang diberikan berdasarkan nilai dari variabel yang lain, dengan mengasumsikan sebuah model ketergantungan linier atau non linier. 
Teknik ini banyak dipelajari dalam statistika, bidang jaringan saraf tiruan (neural network).

c. Klasterisasi (Clustering)

Mempartisi data-set menjadi beberapa sub-set atau kelompok sedemikian rupa sehingga elemen-elemen dari suatu kelompok tertentu memiliki set properti yang di share bersama, dengan tingkat similiritas yang tinggi dalam satu kelompok dan tingkat similiritas antar kelompok yang rendah. Disebut juga dengan 'unsupervised learning'.

d. Asosiasi (Association Rules)

Mendeteksi sekumpulan atribut-atribut yang muncul bersamaan (co-occur) dalam frekuensi yang sering dan membentuk sejumlah kaidah dari kumpulan-kumpulan tersebut.

e. Sekuensial (Sequence Mining)

Mencari sejumlah event yang secara umum terjadi bersama-sama.

Menurut Hermawati (2013:58) Pohon keputusan adalah sebuah struktur data yang terdiri dari simpul (node), dan rusuk (edge). Simpul pada sebuah pohon dibedakan menjadi tiga, yaitu simpul akar (root node), simpul percabangan atau internal (branch/internal node) dan simpul daun (leaf node).

Pohon keputusan merupakan representasi sederhana dari teknik klasifikasi untuk sejumlah kelas berhingga, dimana simpul internal maupun simpul akar ditandai dengan nama atribut, rusukrusuknya diberi label nilai atribut yang mungkin dan simpul daun ditandai dengan kelas-kelas yang berbeda.

Pohon keputusan dibangun berdasarkan suatu algoritma induksi. Salah satu algoritma yang digunakan untuk membangun pohon keputusan yang berbasis algoritma induksi pohon keputusan seperti ID3, C4.5, dan CART adalah algoritma Huntt.

Menurut Hermawati (2013:60) Algoritma C4.5 merupakan algoritma yang digunakan untuk membangun pohon keputusan.

Menurut Kusrini dan luthfi dalam Haryati,dkk (2015) Ada beberapa tahap dalam membuat sebuah pohon keputusan dengan algoritma C4.5, yaitu :

1. Menyiapkan data training,
Data training biasanya diambil dari data histori yang pernah terjadi sebelumnya dan sudah dikelompokkan kedalam kelas-kelas tertentu.

2. Menentukan akar dari pohon.

Akar akan diambil dari atribut yang terpilih, dengan cara menghitung nilai gain dari masing-masing atribut, nilai gain yang paling tinggi yang akan menjadi akar pertama.

Sebelum menghitung nilai gain dari atribut, hitung dahulu nilai entropy. Untuk menghitung nilai entropy digunakan rumus :

Entropy $(s)=\sum_{i=1}^{n}-p i \log 2 p i$

Keterangan :

$\mathrm{S}=$ Himpunan Kasus

$\mathrm{n}=$ jumlah partisi $\mathrm{S}$

$P_{i}=$ Proporsi $S_{i}$ terhadap $S$

3. Kemudian hitung nilai gain menggunakan rumus :

$\operatorname{Gain}(S, A)=$

$$
\text { entropy }(S)-\sum_{i=1}^{n} \frac{|S i|}{S} * \text { Entropy }(S i)
$$

Keterangan :

$\mathrm{S}=$ Himpunan Kasus

$\mathrm{A}=$ Fitur

$\mathrm{n}=$ Jumlah partisi atribut $\mathrm{A}$

$|\mathrm{Si}|=$ Proporsi Si terhadap S

$|S|=$ Jumlah kasus dalam $S$

4. Ulangi langkah ke-2 hingga semua record terpartisi.

5. Proses partisi pohon keputusan akan berhenti saat :

a. Semua record dalam simpul $\mathrm{N}$ mendapat kelas yang sama.

b. Tidak ada atribut didalam record yang dipartisi lagi.

c. Tidak ada record di dalam cabang yang kosong.

\section{METODE}

Metode pengumpulan data pada penelitian ini :

1. Observasi

Observasi dilakukan dengan mendatangkan langsung ke yayasan baitul maal dimana penulismelihat dan mengamati objek secara langsung 
bagaimanasistem seleksi penerimaan beasiswa dilakukan.

2. Wawancara

Dalam metode ini, penulis mengumpulkan data dengan mewawancarai secara langsung pegawai yayasan baitul maal untuk mendapatkan data yang berkaitan dengan penelitian ini.

3. Studi Pustaka

Penulis mencari beberapa data yang diambil dari buku-buku, jurnal dan referensi lainnya yang menunjang penelitian ini.

Penelitian ini merupakan jenis penelitian kuantitatif, dengan menggunakan 18 variabel bebas dan 1 variabel tidak bebas.
Dalam penelitian ini menggunakan proses KDD, yang terdiri dari 5 tahap (Hermawati, 2013):

1. Selection

Data yang didapat dari baitul Maal adalah data calon beasiswa tahun 2010, jumlah data 1535 data. Atribut variabel yang ada sebanyak 18 atribut.

2. Preprocessing

Setelah dilakukan preprocessing data, atribut atau variabel yang digunakan terdiri dari 12 atribut yang terdapat dalam penentuan beasiswa. Dengan 11 atribut predictor dan 1 atribut tujuan. Atribut yang menjadi parameter beasiswa dapat dilihat sebagai berikut :

Tabel 1. Atribut dan nilai katagori

\begin{tabular}{|c|c|c|}
\hline No & Atribut & Nilai \\
\hline \multirow[t]{3}{*}{1} & Usia & \\
\hline & & $21-55$ \\
\hline & & $>55$ \\
\hline \multirow[t]{5}{*}{2} & Pekerjaan & \\
\hline & & Wiraswasta \\
\hline & & Pekerja tetap \\
\hline & & pekerja tidak tetap \\
\hline & & tidak bekerja \\
\hline \multirow[t]{4}{*}{3} & Pendidikan & \\
\hline & & SD \\
\hline & & SMP \\
\hline & & SMA \\
\hline \multirow[t]{3}{*}{4} & Kelas & \\
\hline & & $1-6$ \\
\hline & & $\begin{array}{l}7-9 \\
10-12\end{array}$ \\
\hline \multirow[t]{2}{*}{5} & Kepemilikan & mah tinggal \\
\hline & & Rumah sewa \\
\hline
\end{tabular}




\begin{tabular}{|c|c|c|}
\hline & & $\begin{array}{l}\text { Rumah sendiri } \\
\text { Menumpang }\end{array}$ \\
\hline \multirow[t]{6}{*}{6} & Pendapatan & \\
\hline & & $<500000$ \\
\hline & & $500000-1000000$ \\
\hline & & $1050000-2000000$ \\
\hline & & $>2000000$ \\
\hline & & Tidak ada \\
\hline \multirow[t]{6}{*}{7} & Pengeluaran & \\
\hline & & $<500000$ \\
\hline & & $500000-1000000$ \\
\hline & & $1050000-2000000$ \\
\hline & & $>2000000$ \\
\hline & & Tidak tentu \\
\hline \multirow[t]{4}{*}{8} & Tanggungan $\mathrm{k}$ & eluarga \\
\hline & & 1 \\
\hline & & $2-3$ \\
\hline & & $>3$ \\
\hline \multirow[t]{5}{*}{9} & Peringkat & \\
\hline & & 1 \\
\hline & & $2-3$ \\
\hline & & $4-10$ \\
\hline & & tdk ada \\
\hline \multirow[t]{2}{*}{10} & Organisasi & \\
\hline & & $\begin{array}{l}\text { Aktif Organisasi } \\
\text { tdk ada }\end{array}$ \\
\hline \multirow[t]{5}{*}{11} & Nilai Raport & \\
\hline & & $<60$ \\
\hline & & $60-70$ \\
\hline & & $71-80$ \\
\hline & & $\begin{array}{l}>80 \\
\text { tidak ada }\end{array}$ \\
\hline
\end{tabular}


3. Transformation

Dalam tahap ini, dilakukan eliminasi derau, outliers, missing value. Setelah dilakukan proses tersebut, data yang digunakan menjadi 1120 data dan dengan 12 variabel, seperti pada gambar berikut :

\begin{tabular}{|c|c|c|c|c|c|c|c|c|c|c|c|}
\hline Usia & Pekeljaan & Pendidikan & Kls & Kepemilikan Rumah Tinggal & Pendapatan & Pengeluaran & | Tanggungan Keluarga & |Peringkat| & Organisasi & | Nilai Raport & Remark \\
\hline $21-55$ & Wiraswasta & SD & $1-6$ & Rumah Sewa & $<500000$ & 1050000-2000000 & $2 \cdot 3$ & 4-10 & tdk ada & $>80$ & yes \\
\hline $21-55$ & Wiraswasta & SD & $1 \cdot 6$ & Rumah Sewa & $500000-1000000$ & $500000-1000000$ & $>3$ & tdok ada & tdk ada & $71-80$ & yes \\
\hline $21-55$ & Wiraswasta & SD & 1.6 & Rumah Sewa & $500000-1000000$ & $500000-1000000$ & $2-3$ & $2 \cdot 3$ & tdk ada & $>80$ & yes \\
\hline $21-55$ & Wiraswasta & SD & $1-6$ & Rumah Sewa & $1050000-2000000$ & 1050000-2000000 & $2-3$ & $2-3$ & tdk ada & $>80$ & no \\
\hline $21-55$ & Wiraswasta & SD & 1.6 & Rumah Sendiri & $1050000-2000000$ & 1050000-2000000 & $>3$ & 4-10 & tdk ada & $60-70$ & no \\
\hline $21-55$ & Tidak Bekerja & SD & 1.6 & Rumah Sewa & $500000-1000000$ & tidak tentu & $2 \cdot 3$ & ttdk ada & Aktif Organisasi & $60-70$ & yes \\
\hline $21-55$ & Wiraswasta & SD & $1-6$ & Rumah Sendiri & $500000-1000000$ & $500000-1000000$ & 1 & $2-3$ & tdk ada & $71-80$ & yes \\
\hline $21-55$ & Pekerja Tidak Tetap & SMP & $7-9$ & Rumah Sendiri & $500000-1000000$ & $500000-1000000$ & $2-3$ & ttdk ada & Aktif Organisasi & $60-70$ & no \\
\hline$>55$ & Wiraswasta & SMP & 7.9 & Menumpang & $500000-1000000$ & 500000-1000000 & $2 \cdot 3$ & 1 & tdk ada & $71-80$ & yes \\
\hline $21-55$ & Pekerja Tidak Tetap & SMP & $7-9$ & Rumah Sendiri & $1050000-2000000$ & $1050000-2000000$ & $>3$ & ttdk ada & Aktif Organisasi & $60-70$ & no \\
\hline $21-55$ & Pekerja Tidak Tetap & SMA & 10-12 & Rumah Sendiri & $1050000-2000000$ & $1050000-2000000$ & $>3$ & $2-3$ & tdk ada & $>80$ & yes \\
\hline $21-55$ & Pekerja Tetap & SMP & 7.9 & Rumah Sendiri & $500000-1000000$ & $500000-1000000$ & $2 \cdot 3$ & $2 \cdot 3$ & tdk ada & $60-70$ & yes \\
\hline $21-55$ & Pekerja Tidak Tetap & SMA & $10-12$ & Rumah Sendiri & $<500000$ & $500000-1000000$ & $>3$ & ttdk ada & Aktif Organisasi & $71-80$ & yes \\
\hline $21-55$ & Pekerja Tidak Tetap & SMA & 10-12 & Menumpang & $\angle 500000$ & 500000-1000000 & $>3$ & ttdk ada & Aktif Organisasi & $71-80$ & yes \\
\hline $21-55$ & Wiraswasta & SMP & $7-9$ & Rumah Sendiri & $500000-1000000$ & $<500000$ & $2-3$ & ttdk ada & Aktif Organisasi & $60-70$ & no \\
\hline $21-55$ & Wiraswasta & SD & 1.6 & Rumah Sewa & $500000-1000000$ & 1050000-2000000 & $2-3$ & $2 \cdot 3$ & tdk ada & $71-80$ & yes \\
\hline $21-55$ & Pekerja Tidak Tetap & SMP & 7.9 & Rumah Sendiri & 500000-1000000 & $<500000$ & $2 \cdot 3$ & tdk ada & tdk ada & $60-70$ & no \\
\hline
\end{tabular}

Gambar 1. Data Hasil Tahap Transformation

\section{Data mining}

Pada tahap ini, dilakukan pemrosesan data yang diklasifikasikan oleh model dan kemudian menghasilkan sejumlah aturan. Pada penelitian ini menggunakan algoritama C4.5 menggunakan langkah-langkah dalam algoritma C4.5.

5. Interpretation/evalution

Pada tahap ini dilakukan analisa pola yang didapat dari data mining.

\section{HASIL DAN PEMBAHASAN}

Penelitian ini bertujuan untuk menentukan kriteria pemberian beasiswa dengan menggunakan algoritma C4.5, dengan langkah-langkah sebagai berikut:

1. Siapkan data training. Data training yang digunakan dalam tahap ini berjumlah 1120 record.

2. Hitung nilai entropy.
Berdasarkan menggunakan rumus (1) pada metode penelitian untuk perhitungan entropy, didapat entropy sebagai berikut :

entropy $(\mathrm{S})=$

$(-571 / 1120 * \log 2(571 / 1120))+(-$

$549 / 1120 * \log 2(549 / 1120))=0.99972165$ 6

3. Setelah itu, hitung nilai gain untuk setiap atribut menggunakan rumus (2) pada metode penelitian, Ialu pilih nilai gain yang tertinggi. Nilai gain yang tertinggi yang dijadikan akar dari pohon. Contoh perhitungan gain untuk atribut usia :

Gain $(S, A)=$

0.99 -

$((1029 / 1120 * 0.999)+(91 / 1120 * 0.9978)=$ 0.0000796

Berikut hasil perhitungan nilai entropy dan gain, sebagai berikut : 
Tabel 2. Hasil Entropy dan Gain

\begin{tabular}{|c|c|c|c|c|c|}
\hline simpul & kasus & Yes & No & entropy & gain \\
\hline Usia & 1120 & 571 & 549 & 0.9997 & 0.0000796 \\
\hline $21-55$ & 1029 & 523 & 506 & 0.9998 & \\
\hline$>55$ & 91 & 48 & 43 & 0.9978 & \\
\hline Pekerjaan & 1120 & 571 & 549 & & 0.008979 \\
\hline Wiraswasta & 495 & 279 & 216 & 0.9883 & \\
\hline Pekerja tetap & 137 & 57 & 80 & 0.9796 & \\
\hline pekerja tidak tetap & 417 & 206 & 211 & 0.9999 & \\
\hline tidak bekerja & 71 & 29 & 42 & 0.9757 & \\
\hline Pendidikan & 1120 & 571 & 549 & & -0.0298363 \\
\hline SD & 451 & 231 & 220 & 1.0356 & \\
\hline SMP & 371 & 181 & 190 & 0.9654 & \\
\hline SMA & 298 & 159 & 139 & 1.1002 & \\
\hline Kelas & 1120 & 571 & 549 & & 0.0009661 \\
\hline $1-6$ & 452 & 232 & 220 & 0.9995 & \\
\hline $7-9$ & 370 & 180 & 190 & 0.9995 & \\
\hline $10-12$ & 298 & 159 & 139 & 0.9967 & \\
\hline Kepemilikan rumah tinggal & 1120 & 571 & 549 & & 0.0016925 \\
\hline Rumah sewa & 161 & 84 & 77 & 0.9986 & \\
\hline Rumah sendiri & 675 & 354 & 321 & 0.9983 & \\
\hline Menumpang & 284 & 133 & 151 & 0.9971 & \\
\hline Pendapatan & 1120 & 571 & 549 & & 0.0058606 \\
\hline$<500000$ & 217 & 127 & 90 & 0.9789 & \\
\hline $500000-1000000$ & 709 & 359 & 350 & 0.9999 & \\
\hline $1050000-2000000$ & 167 & 73 & 94 & 0.9886 & \\
\hline$>2000000$ & 6 & 3 & 3 & 1.0000 & \\
\hline Tidak ada & 21 & 9 & 12 & 0.9852 & \\
\hline Pengeluaran & 1120 & 571 & 549 & & 0.0026098 \\
\hline$<500000$ & 194 & 97 & 97 & 1.0000 & \\
\hline $500000-1000000$ & 503 & 270 & 233 & 0.9961 & \\
\hline $1050000-2000000$ & 326 & 161 & 165 & 0.9999 & \\
\hline$>2000000$ & 26 & 13 & 13 & 1.0000 & \\
\hline Tidak tentu & 71 & 30 & 41 & 0.9826 & \\
\hline Tanggungan keluarga & 1120 & 571 & 549 & & 0.0001041 \\
\hline 1 & 145 & 74 & 71 & 0.9997 & \\
\hline $2-3$ & 679 & 349 & 330 & 0.9994 & \\
\hline$>3$ & 296 & 148 & 148 & 1.0000 & \\
\hline Peringkat & 1120 & 571 & 549 & & 0.0258829 \\
\hline 1 & 116 & 82 & 34 & 0.8727 & \\
\hline $2-3$ & 131 & 81 & 50 & 0.9592 & \\
\hline 4-10 & 129 & 76 & 53 & 0.9769 & \\
\hline tdk ada & 744 & 332 & 412 & 0.9916 & \\
\hline Organisasi & 1120 & 571 & 549 & & 0.0192509 \\
\hline Aktif Organisasi & 572 & 246 & 326 & 0.9858 & \\
\hline tdk ada & 548 & 325 & 223 & 0.9749 & \\
\hline Nilai Raport & 1120 & 571 & 549 & & 0.1503534 \\
\hline$<60$ & 10 & 0 & 10 & 0.0000 & \\
\hline $60-70$ & 315 & 85 & 230 & 0.8412 & \\
\hline $71-80$ & 576 & 365 & 211 & 0.9478 & \\
\hline$>80$ & 155 & 118 & 37 & 0.7929 & \\
\hline
\end{tabular}




\begin{tabular}{rllll}
\hline tidak ada & 64 & 3 & 61 & 0.2730 \\
\hline & 1120 & 571 & 549 & \\
\hline
\end{tabular}

Dari Tabel 2, terlihat bahwa atribut nilai raport mempunyai nilai gain tertinggi yaitu 0.150353351 . Oleh karena itu, nilai raport dijadikan simpul akar pada pohon keputusan.

Selanjutnya menentukan simpul berikutnya, yaitu simpul 1.1, dengan dilakukan perhitungan entropy dan gain masing-masing atribut dari nilai raport.

Setelah dilakukan perhitungan entropy dan gain untuk seleruh atribut dalam kelas, maka akan didapat sebuah pohon keputusan seperti dibawah ini :

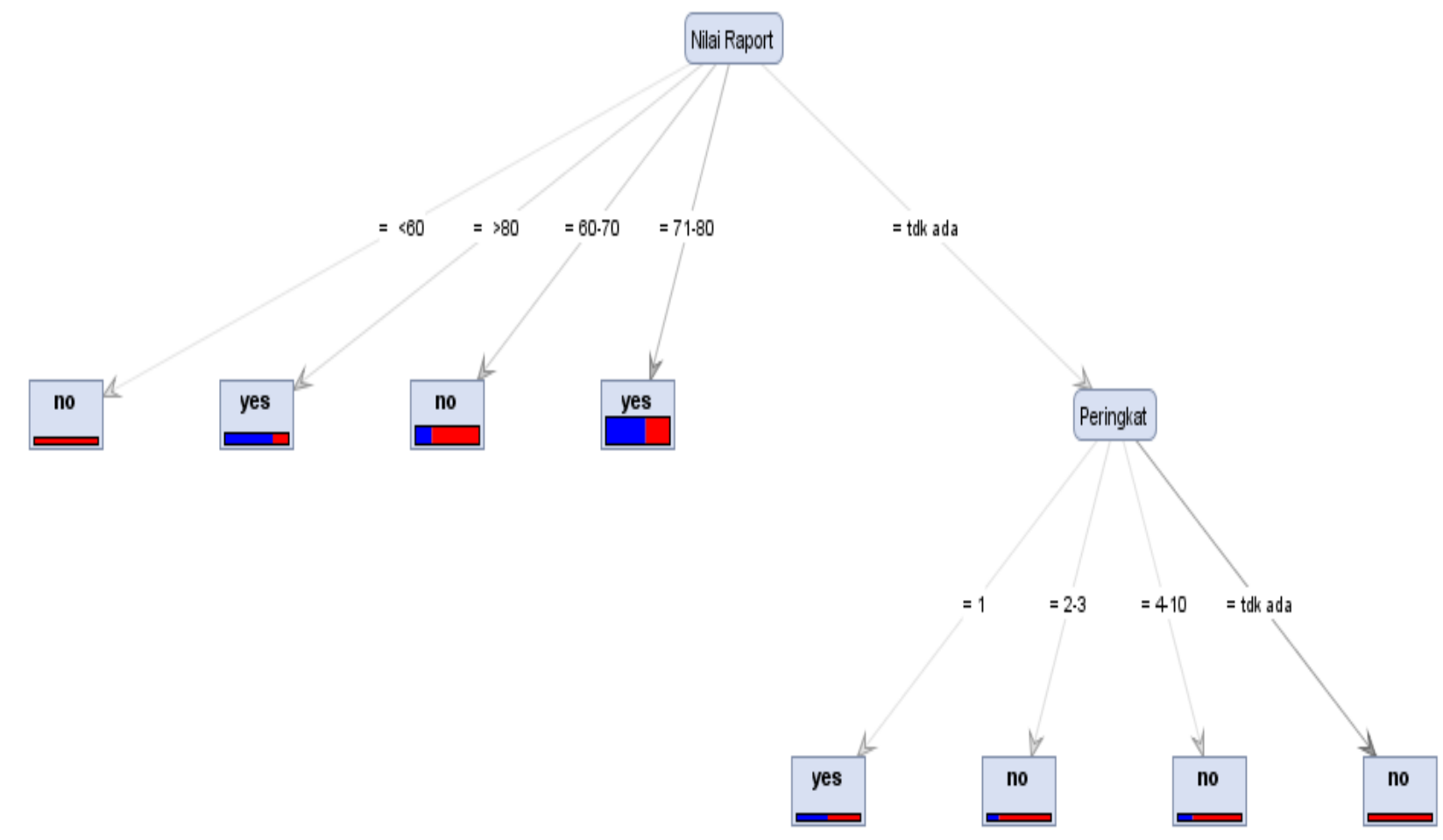

Gambar 2. Pohon keputusan menggunakan algoritma C4.5

\begin{tabular}{|c|c|}
\hline 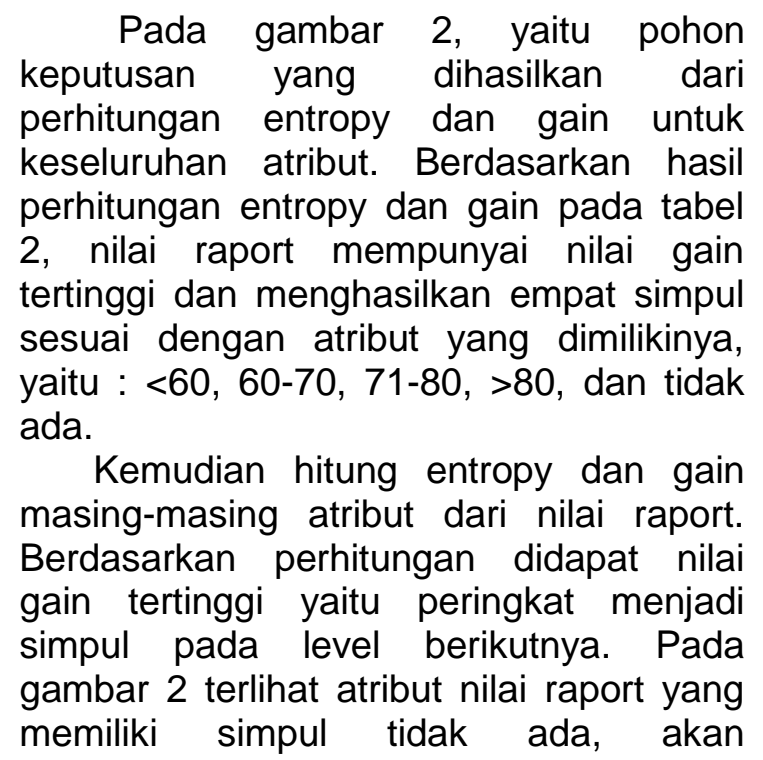 & $\begin{array}{l}\text { membentuk cabang kedua, yaitu: }=1,=2- \\
3,=4-10 \text {, dan tidak ada. Berdasarkan } \\
\text { pohon keputusan pada gambar } 2 \text {, dapat } \\
\text { membentuk aturan-aturan, yaitu sebagai } \\
\text { berikut: } \\
\text { a. R1: If Nilai Raport tidak ada AND } \\
\text { Peringkat tidak ada THEN no } \\
\text { b. R2: If Nilai Raport tidak ada AND } \\
\text { Peringkat } 4-10 \text { THEN no } \\
\text { c. R3: If Nilai Raport tidak ada AND } \\
\text { Peringkat } 2-3 \text { THEN no } \\
\text { d. R4: If Nilai Raport tidak ada AND } \\
\text { Peringkat } 1 \text { THEN yes } \\
\text { e. R5: If Nilai Raport } 71-80 \text { THEN yes } \\
\text { f. R6: If Nilai Raport } 60-70 \text { THEN no } \\
\text { g. R7: If Nilai Raport } \geq 80 \text { THEN yes } \\
\text { h. R8: If Nilai Raport } \leq 60 \text { THEN no }\end{array}$ \\
\hline
\end{tabular}


Sehingga berdasarkan rule diatas dihasilkan pengambilan keputusan yang beasiswa berdasarkan kriteria:

1. Jika siswa atau siswi Nilai Raportnya tidak ada dan Peringkatnya tidak ada maka siswa atau siswi tersebut tidak mendapatkan beasiswa.

2. Jika siswa atau siswi Nilai Raportnya tidak ada dan Peringkatnya 4-10 maka siswa atau siswi tersebut tidak mendapatkan beasiswa.

3. Jika siswa atau siswi Nilai Raportnya tidak ada dan Peringkatnya 2-3 maka siswa atau siswi tersebut tidak mendapatkan beasiswa.

4. Jika siswa atau siswi Nilai Raport tidak ada dan Peringkatnya 1 maka siswa atau siswi tersebut mendapatkan beasiswa.
5. Jika siswa atau siswi Nilai Raport 71-80 maka siswa atau siswi tersebut mendapatkan beasiswa.

6. Jika siswa atau siswi Nilai Raport 60-70 maka siswa atau siswi tersebut tidak mendapatkan beasiswa.

7. Jika siswa atau siswi Nilai Raport $>=80$ maka siswa atau siswi tersebut mendapatkan beasiswa.

8. Jika siswa atau siswi Nilai Raport $<=60$ maka siswa atau siswi tersebut mendapatkan beasiswa.

Tahap akhir dalam penelitian ini dengan melakukan tahap pengujian tingkat akurasi dengan menggunakan confussion matrix dan kurva ROC/AUC (Area Under Cover), dengan rapidminer. Berikut hasil Confussion matrix dan kurva ROC/AUC (Area Under Cover), dengan rapidminer :

\begin{tabular}{|c|c|c|c|}
\hline & trueyes & true no & class precision \\
\hline pred yes & 483 & 251 & $65.80 \%$ \\
\hline pred. no & 88 & 298 & $77.20 \%$ \\
\hline class recall & $84.59 \%$ & $54.28 \%$ & \\
\hline
\end{tabular}

\section{Gambar 3. Confussion matrix algoritma C4.5}

Berdasarkan gambar 3. Perhitungan akurasi data training menggunakan algoritma C4.5. Diketahui dari 1120 data dan 11 atribut (usia, pekerjaan, pendidikan, kelas, kepemilikan rumah tinggal, pendapatan, pengeluaran, tanggungan keluarga, peringkat, organisasi, nilai raport), dengan menggunakan algoritma C4.5 menghasilkan akurasi sebesar 69,73\%, didapat 483 data prediksi yes sesuai dengan yes, 251 prediksi yes ternyata no, 88 data prediksi no ternyata yes dan 298 data predisi no sesuai dengan no.

\section{SIMPULAN DAN SARAN}

Penelitian ini digunakan untuk mendukung keputusan pemberian beasiswa dengan menggunakan algoritma C4.5 yang dapat membantu pemberian beasiswa bagi siswa atau siswi sekolah dasar (SD), Sekolah Lanjutan Tingkat Atas (SLTP), dan Sekolah Lanjutan Tingkat Atas (SLTA). Dalam penelitian ini didapat kriteria penentu utama beasiswa yaitu nilai raport, jika nilai raportnya tidak ada maka dengan melihat data peringkat, jika peringkat 1 maka dapat beasiswa, tetapi jika tidak ada peringkat tidak mendapat beasiswa. Atribut yang lainnya tidak termasuk dalam penentuan beasiswa. Penelitian ini melakukan pengujian dengan menggunakan confussion matrix dan kurva ROC/AUC (Area Under Cover), dengan hasil $69,73 \%$.

Saran dari penelitian ini :

1. Penelitian ini dilakukan dengan menggunakan data calon beasiswa dari satu lembaga saja. Apabila dilakukan penelitian yang sama dapat dilakukan di lembaga atau perusahaan lain dengan atribut yang bervariasi, 
sehingga mendapatkan hasil yang berbeda.

2. Menambahkan jumlah atribut yang lebih banyak, sehingga diperoleh pengukuran yang lebih baik lagi.

3. Menggunakan model data mining yang lainnya, agar didapat hasil yang berbeda dengan tingkat akurasi yang berbeda.

\section{DAFTAR RUJUKAN}

Ahda, Fadhli Almu'iini dan Saiful Bahri. 2017. Sistem Pendukung Keputusan Pemberian BeasiswaUntuk Siswa Kurang Mampu Di SMK Muhammadiyah 1 Kepanjen Menggunakan Metode Fuzzy Tsukamoto. Jurnal Spirit. Vol 9 No.2 Nopember 2017, hal 48-56. ISSN : 2085-3092. STMIK ASIA Malang.

Arikunto, Suharsimi. 2014. Prosedur Penelitian. Jakarta: Rineka Cipta.

Guterres, Jose Augusto Duarte. 2015. Kelayakan Algoritma C4.5 Sebagai Pendukung Keputusan Dalam Pengajuan Penerimaan Beasiswa. Seminar Nasional Teknologi Informasi.

Haryati, Siska, Aji Sudarsono, Eko Suryana. 2015. Implementasi Data Mining Untuk Memprediksi Masa Studi Mahasiswa Menggunakan Algoritma C4.5 (Studi Kasus UniversitasDehasean Bengkulu). Jurnal Media Infotama, Universitas Dehasen Bengkulu.

Hermawati, Fajar Astuti. 2013. Data Mining. Yogyakarta: Andi Offset.

Hijriana, Nadiya dan Muhammad Rasyidan. 2017. Penerapan Metode Decision Tree Algoritma C4.5 Untuk Seleksi Calon Penerima Beasiswa Tingkat Universitas. Al Ulum Sains dan Teknologi Vol. 3 No. 1 Nopember 2017.

Muslihudin, Muhamad. 2017. Sistem Pendukung Keputusan Menentukan
Kelayakan Penerimaan Bantuan Pengusaha Ayam Petelur Oleh Dinas Peternakan Kabupaten Pesawaran Menggunakan Metode Simple Additive Weighting. Jurnal Pendidikan Teknologi dan kejuruan Vol.14, No.2, Juli 2017, Hal:120. PISSN : 0216-3241; E-ISSN : 2541 065.

Nurtanto, M, M, Fawaid, Y. Fargianti, S.D. Ramdani, dan S.Nurhaji. Faktor Pengaruh Minat Masuk Perguruan Tinggi Di SMK Serang. Jurnal Pendidikan Teknologi dan Kejuruan Vol. 14, No. 1, Januari 2017, Hal : 11 P-ISSN : 0216-3241; E-ISSN : 2541-0652.

Praja, Mahindra Suryaning dan Erna Zuni Astuti. 2016. Penerapan Data Mining Untuk Rekomendasi Beasiswa Pada SMA N 1 Mlonggo Menggunakan Algoritma C4.5. Universitas Dian Nuswantoro,Semarang, skripsi 2016.

Prasetyo, Eko. 2012. Data Mining Konsep dan Aplikasi Menggunakan MATLAB. Yogyakarta: Andi Yogyakarta.

Rainer, dedi. 2017. Pengertian Beasiswa, Tujuan, Syarat, Manfaat, Jenis, Contoh Terlengkap. http://www.studinews.co.id.

Suryadi, Achmad. 2007. Analisa Manajemen Pengambilan Keputusan. Surabaya: Graha IImu.

Vulandari, Retno Tri. 2017. Data Mining Teori dan Aplikasi Rapidminer. Yogyakarta: Gava Media. 